\title{
PETROLOGY OF KIMBERLITE-LAMPROITE-CARBONATITE ROCK ASSOCIATION, EAST PRIANABAR'E (RUSSIA)
}

\author{
Nikolai Vladykin ${ }^{1}$, Mikhail Lelyukh², Aleksandr Tolstov ${ }^{2}$ and Valerii Serov². \\ ${ }^{1}$ Institute of Geochemistry, SB RAS, Irkutsk, Russia; ${ }^{2}$ ALROSA Company Ltd. Mirny, Russia.
}

As was shown earlier (Dawson, 1980) kimberlites occur within a central part of the platform while alkaline massifs are found on its margins. This feature is typical of the Siberian Platform as well. However, the Siberian Platform is marked by some peculiar features. We studied an association of lamproites with K-alkaline rocks, occurring in rift zones between the south part of the Siberian Platform and Aldan shield (Vladykin, 1985, 1997). Over 1000 diatreme anomalies of picritekimberlite composition and a large alkaline Tomtor massif with ore $\mathrm{Nb}-\mathrm{Tr}$ carbonatites are found in the northern part between the platform and eastern framing of the Anabar shield. The Ebelyakh placer diamond deposit is located between them.

Lamproite rocks are observed in many diatremes of the Eastern Prianabar'e (Vladykin, et al., 1998). A complete composition series from kimberlites (picrites, alnoites) to lamproites is found here. In addition to syenites and ijolites the Tomtor massif contains abundant olivine and monticellite picrites, alneites, melilites, olivine and leucite lamproites (Vladykin $2000,2002)$. A new scheme of magmatism was proposed for this massif. All rocks are significantly carbonatized and are cut by carbonatite dykes. A method to dissolve secondary carbonatites in $\mathrm{HCl}$ was developed to restore a primary lamproite composition (Vladykin, 2002).

On petrochemical diagrams of binary and ternary correlations (over 1000 silicate analyses) all rocks of the association form a common trend It indicates genetic similarity of all rocks from the association.

The distribution pattern of rare elements $(\mathrm{Ba}, \mathrm{Sr}, \mathrm{Cr}$, $\mathrm{Ni}$, etc.) is similar to that of petrogenic elements. Eu fractionation is absent on TR spectra of all rocks that is due to the absence of plagioclase in K-magmas. In carbonatites TR spectra lines have a common inclination and are different only in total TR concentrations. TR spectra in lamproites of Prianabar'e are completely comparable with those in Australian lamproites.

On $\mathrm{Sr} / \mathrm{Nd}$ diagram picrites, lamproites and carbonatites of the Eastern Prianabar'e form a common trend in the field of kimberlites 1 between a field of depleted mantle and that of enriched EM-1 mantle.
Mantle xenoliths of dunites, picroilmenitic gimmerites, harzburgites and eclogites are found in picrite-lamproite rocks of the Eastern Prianabar'e. $\mathrm{Cr} 2 \mathrm{O} 3$ content in garnets amounts to $46 \%$ while in spinel it varies from 20 to $60 \%$.From different mineral thermobarometers we have obtai- ned the following parameters of mantle xenolith formation: P- 45-55 kbars, $\mathrm{t}^{\circ}-1000^{\circ}-1200^{\circ} \mathrm{C}$.

The magmatic evolution in the Eastern Prianabar'e is associated with mantle plume processes. From a wide occurrence of volcanic and tuffaceous rocks in the Tomtor volcanic pluton it can be inferred that a source of diamond-bearing Ebelyakh placer was lamproite tuffs, which are found in $50 \mathrm{~km}$ away from the placer. 10 point size, fully justified with exactly 12 point line spacing. 